\title{
James R. Simpson, Fantasy, Identity and Misrecognition in Medieval French Narrative
}

\section{G. Matteo Roccati}

\section{Q OpenEdition}

10 Journals

\section{Édition électronique}

URL : https://journals.openedition.org/studifrancesi/40263

DOI : $10.4000 /$ studifrancesi.40263

ISSN : 2421-5856

\section{Éditeur}

Rosenberg \& Sellier

\section{Édition imprimée}

Date de publication : 1 juillet 2004

Pagination : 156

ISSN : 0039-2944

\section{Référence électronique}

G. Matteo Roccati, « James R. Simpson, Fantasy, Identity and Misrecognition in Medieval French Narrative », Studi Francesi [En ligne], 142 (XLVIII | I) | 2004, mis en ligne le 30 novembre 2015, consulté le 09 septembre 2021. URL : http://journals.openedition.org/studifrancesi/40263 ; DOI : https:// doi.org/10.4000/studifrancesi.40263

Ce document a été généré automatiquement le 9 septembre 2021.

\section{(c)}

Studi Francesi è distribuita con Licenza Creative Commons Attribuzione - Non commerciale - Non opere derivate 4.0 Internazionale. 


\title{
James R. Simpson, Fantasy, Identity and Misrecognition in Medieval French Narrative
}

\author{
G. Matteo Roccati
}

\section{RÉFÉRENCE}

JAMES R. SIMPSON, Fantasy, Identity and Misrecognition in Medieval French Narrative, Bern, Peter Lang, 2000; pp. 290.

1 Commentaire lacanien de quetques textes narratifs du XIII ${ }^{\mathrm{e}}$ et du début du XIV ${ }^{\mathrm{e}}$ siècle. Le premier chapitre traite de «the foundational and destructive place of the hero in the rhymed Paris version of the Chanson de Roland and his sequel, Gaydon» (p. 6); le deuxième est consacré à Anseïs de Carthage où «the central relationship is between the young king and two versions of the Imaginary father» (p. 8); le troisième examine le rôle de l'auteur et le rapport à Ovide dans l'ovide moralisé, enfin le quatrième est une lecture de Trubert en termes sado-masochistes. On trouvera en appendice les résumés des oeuvres (I, pp. 243-254, sauf l'O.m.) et un petit glossaire des concepts psychanalytiques utilisés (II, pp. 255-270). La bibliographie (pp. 271-286) et l'index (pp. 287-290) terminent le volume. 